\title{
Early Spawning by the American Brook Lamprey (Lethenteron appendix) in Southeastern Minnesota
}

\author{
Philip A. Cochran ${ }^{1}$, Mark A. Ross ${ }^{1}$, Thomas S. WALKer ${ }^{1}$, and Trevor Biederman ${ }^{2}$ \\ ${ }^{1}$ Biology Department, Saint Mary's University of Minnesota,700 Terrace Heights, Winona, Minnesota 55987 United States; \\ e-mail: pcochran@smumn.edu \\ 2315 West Mills Street, Winona, Minnesota 55987 United States
}

Cochran, Philip A., Mark A. Ross, Thomas S. Walker, and Trevor Biederman. 2012. Early spawning by the American Brook Lamprey (Lethenteron appendix) in southeastern Minnesota. Canadian Field-Naturalist 126(3): 204-209.

Record-setting warm temperatures in the upper Midwest during early 2012 resulted in early spawning by the American Brook Lamprey (Lethenteron appendix) in southeastern Minnesota. American Brook Lampreys in a total of five streams in three drainages spawned up to one month earlier than typical. Mean day of year of spawning groups observed in 2012 was significantly different from the mean for groups observed during the period 2002-2010, but mean water temperature was not significantly different. Limited historical data are not sufficient to show an effect of climate change on spawning phenology because some data are confounded with the effects of latitude and year-to-year variability in thermal regime.

Key Words: American Brook Lamprey, Lethenteron appendix, Lampetra appendix, climate, Petromyzontidae, reproductive phenology, spawning, temperature, Minnesota, Wisconsin, Iowa.

Record-setting high temperatures were recorded in the upper Midwestern U.S. in early 2012. In Minnesota, the month of March 2012 was the warmest on record, based on data for a 118-year period (1895-2012), and January (the fifth warmest) and February (the tenth warmest) were also exceptional (U.S. National Oceanic and Atmospheric Administration 2012*). At a local level, March was the warmest on record for Winona, Minnesota (data available back to 1893), Rochester, Minnesota (1896), and LaCrosse, Wisconsin (1873) (U.S. National Weather Service 2012*). Temperatures in Rochester exceeded $27^{\circ} \mathrm{C}$ on 17 and 18 March (Minnesota Climatology Working Group 2012*). The exceptionally warm spring in 2012 affected many phenological events (Zimmer 2012*). For example, Lake Sturgeon (Acipenser fulvescens) began spawning in the Lake Winnebago system in Wisconsin on 20 March, the earliest start on record (Mentzer 2012*).

The purpose of this note is to report exceptionally early spawning by the American Brook Lamprey (Lethenteron appendix) in southern Minnesota. Until recently this species was known as Lampetra appendix (Lang et al. 2009).

Like other lampreys, American Brook Lampreys spend most of their lives as filter-feeding larvae, or ammocoetes, which burrow into areas of fine sediment in streams. After undergoing metamorphosis to the adult phase, they spawn in areas of coarse bottom, usually just upstream from riffles. American Brook Lampreys do not feed as adults, and they die after spawning. Spawning periods within individual streams are typically brief (only a few days in duration) (Cochran et al.1993), and spawning is localized within streams (Mundahl and Sagan 2005).
The American Brook Lamprey has been well studied in Minnesota and Wisconsin (Cochran 1984; Cochran et al. 1993; Mundahl and Sagan 2005; Mundahl et al. 2005; Mundahl et al. 2006; Cochran 2008; Cochran et al. 2008), and its spawning season in this region has been fairly well defined. In Wisconsin, Cochran (1984) observed spawning in Waukesha County on 25 April 1982, and Cochran et al. (1993) reported spawning in Rock County on 4 May 1984 and in Manitowoc County on 2 May 1988, 3 and 4 May 1989, and 6 May 1992. In Minnesota, Mundahl and Sagan (2005) observed spawning in southeastern Minnesota streams during the periods 25 April-11 May 1995, 28 April-9 May 1996, and 21-29 April 1997. Water temperatures during spawning were reviewed by Cochran et al. (1993); although spawning has been reported over a wide range of temperatures $\left(6.7^{\circ} \mathrm{C}-20.6^{\circ} \mathrm{C}\right)$, its onset most often occurs at a temperature of $10^{\circ} \mathrm{C}-15^{\circ} \mathrm{C}$.

\section{Methods}

2012 surveys

After initial observations of early spawning in Rush Creek (Root River drainage basin) in Winona County, additional surveys for spawning were conducted in the Upper Iowa River drainage basin in Mower County and in the Whitewater River drainage basin in Winona County (locations are detailed in Table 1). Surveys were conducted by wading through typical spawning habitat, including locations where American Brook Lampreys had been observed spawning in the past. In some cases, video-recordings of spawning were obtained.

A distinction was made between spawning groups and "stragglers." Stragglers, also referred to as "loners" (Mundahl and Sagan 2005), are solitary adults present 
TABLE 1. Locations where American Brook Lampreys (Lethenteron appendix) were observed during the present study. Each drainage is a separate system tributary to the Mississippi River.

\begin{tabular}{lllll}
\hline County & Drainage & Stream & Latitude & Longitude \\
\hline Winona & Whitewater River & North Branch Whitewater & 44.086 & -92.034 \\
Winona & Whitewater River & South Branch Whitewater & 44.070 & -91.979 \\
Winona & Whitewater River & Beaver Creek & 44.152 & -92.028 \\
Winona & Trout Creek & Trout Creek & 43.996 & -91.461 \\
Winona & Trout Creek & Trout Creek & 43.981 & -91.496 \\
Winona & Root River & Rush Creek & 43.872 & -91.813 \\
Houston & Wildcat Creek & Wildcat Creek & 43.689 & -91.293 \\
Mower & Upper Iowa River & Upper Iowa River & 43.519 & -92.500 \\
Howard & Upper Iowa River & Upper Iowa River & 43.494 & -92.358 \\
Howard & Upper Iowa River & Beaver Creek & 43.460 & -92.308 \\
Howard & Upper Iowa River & Staff Creek & 43.493 & -92.391 \\
\hline \hline
\end{tabular}

in typical spawning habitat. Sometimes they are present early in the spawning season and may simply represent the first individuals to arrive in the spawning habitat. Sometimes they are present after spawning has peaked and may represent spent individuals that have not yet died. Thus, stragglers may introduce variability into data compiled for spawning groups.

\section{2-2010 data}

Data on spawning by the American Brook Lamprey in Winona County during the period 2002-2010 were compiled from field notes recorded by PAC. These include observations made during the study by Cochran et al. (2008) of spawning behavior, as well as incidental records obtained during the course of other projects.

Because the American Brook Lamprey dies after spawning, the collection of living adult specimens at a given location during a fish survey indicates that spawning has not yet been completed at that site. Therefore, data on occurrence of adults in spring fish collections conducted by PAC in southeastern Minnesota and adjacent Iowa were also compiled.

Statistical comparisons between spawning data for 2012 and 2002-2010 were conducted by using $t$-tests. Each comparison was conducted with data for stragglers included and with data for stragglers excluded.

\section{Historical data}

American Brook Lampreys are typically noticed by members of the general public only during the spawning season, when they are especially likely to be encountered by trout fishers. A search for historical records of American Brook Lampreys in southeastern Minnesota and adjacent Wisconsin was conducted by taking advantage of the Winona Newspaper Project, a website that permits electronic searches of Winona newspapers published during the 19th and early 20th centuries (www.winona.edu/library/databases/winona newspaperproject.htm).

\section{Results}

\section{2 surveys}

Over 20 groups of American Brook Lampreys were observed spawning on 22 March in Rush Creek up- stream from the more southern County Road 25 crossing. Water temperature was $14^{\circ} \mathrm{C}$. A captured female spontaneously released eggs when handled, and a video-recording of a spawning group revealed typical mating behavior as well as attachment by multiple males to single females (Cochran et al. 2008). No American Brook Lampreys were observed when the site was revisited on 27 March.

Spawning was in progress on 24 March when we surveyed the Upper Iowa River at the Mower County Road 12 crossing upstream from Leroy. Three spawning groups were observed, as well as four apparent nests with single spawners. Water temperature was $17^{\circ} \mathrm{C}$.

In the Whitewater River drainage basin, observations were made in three streams: the North Branch Whitewater River, the South Branch Whitewater River, and Beaver Creek. In the North Branch Whitewater River upstream from Elba, no American Brook Lampreys were observed on $24 \mathrm{March}$ (water temperature $12.5^{\circ} \mathrm{C}$ ) or 27 March (water temperature $13.5^{\circ} \mathrm{C}$ ), but one straggler was observed on a nest on 29 March (water temperature $13^{\circ} \mathrm{C}$ ). No American Brook Lampreys were observed on 2 April (water temperature $10^{\circ} \mathrm{C}$ ), but some apparent nests were present. In the South Branch Whitewater River near Crystal Springs, a straggler was observed in typical spawning habitat on 30 March (water temperature not available), but no American Brook Lampreys were observed on 2 April (water temperature $10^{\circ} \mathrm{C}$ ). In Beaver Creek west of County Road 116, several spawning groups were present on 2 April (water temperature not available), and a video-recording revealed both typical mating and satellite male behavior (Cochran et al. 2008). A single straggler was observed on 4 April (water temperature $9.5^{\circ} \mathrm{C}$ ).

\section{2-2010 data}

Spawning groups of American Brook Lampreys were observed on six occasions between 19 and 25 April, and stragglers were observed on three occasions between 10 and 27 April (Figure 1). Mean date of observed spawning was significantly different between 2002-2010 and 2012, regardless of whether stragglers were included $(t=8.857, P=0.000)$ or excluded $(t=$ $7.425, P=0.013)$. 


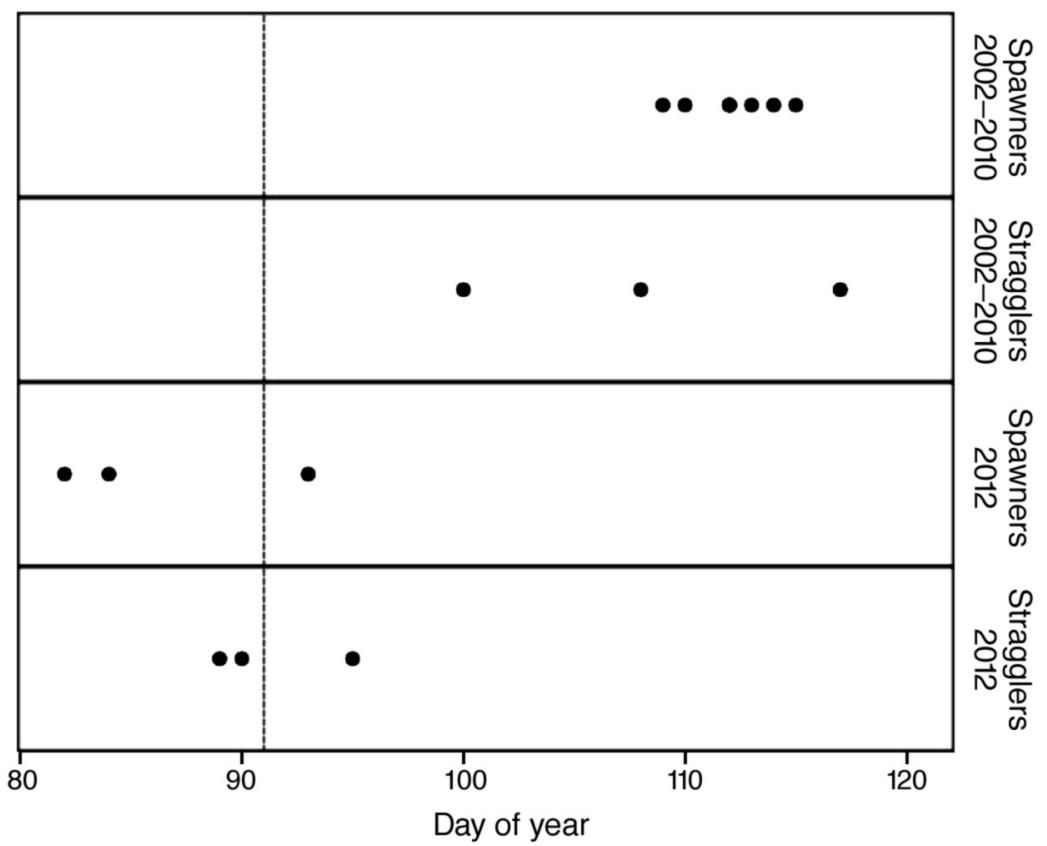

FIGURE 1. Dot plots of day of year (January $1=$ day 1, December $31=$ day 365) when spawning-phase American Brook Lampreys (Lethenteron appendix)were observed in southeastern Minnesota during the period 2002-2010 and during the exceptionally warm spring of 2012. Data are presented separately for spawning groups and stragglers. The vertical reference line indicates April 1.

Water temperatures were not always recorded when American Brook Lampreys were observed. However, during the period 2002-2010, spawning groups or stragglers were observed at water temperatures of $8^{\circ} \mathrm{C}-$ $16^{\circ} \mathrm{C}$ (Figure 2). Mean water temperature was not significantly different between 2002-2010 and 2012, regardless of whether stragglers were included $(t=$ $0.289, P=0.780)$ or excluded $(t=1.576, P=0.176)$.

We collected adult American Brook Lampreys on the following dates and locations in southeastern Minnesota: on 6 April and 8 April 2008 at two locations in Trout Creek (Winona County) and on 21 April 2008 in Wildcat Creek (Houston County). We also collected adults on 25 April 2011 in three streams in the Upper Iowa River drainage basin (Beaver Creek, Staff Creek, and Upper Iowa River) just south of the Minnesota border in Howard County, Iowa. Despite the relatively late date, water temperatures in the Iowa streams remained relatively cool $\left(9^{\circ} \mathrm{C}-12^{\circ} \mathrm{C}\right)$. At none of the locations in Minnesota or Iowa did we observe any indications that spawning had yet occurred.

\section{Historical data}

Our search of Winona newspapers yielded two accounts of brook lampreys associated with spawning. Both occurred in the 1950s at a time when concern about the Sea Lamprey (Petromyzon marinus) in the Great Lakes led to heightened awareness of native lam- preys in other systems. One article (Anonymous 1950*) reported that trout fishers collected lamprey specimens averaging 17.5-20 cm in Beaver Creek (Trempealeau County, Wisconsin) and that lampreys had also been observed in Pigeon and Elk creeks. It was suggested that a "late spring" had resulted in lamprey spawning occurring after the onset of the trout fishing season. In a second article (Anonymous $1956^{*}$ ), a photograph of a specimen collected on 6 May 1956 in Pine Creek (Root River drainage basin, Winona and Fillmore counties) appeared with commentary that other reports had been received during the previous two weeks. American Brook Lampreys have been documented from the streams mentioned in both articles (Fago 1983; Mundahl and Sagan 2005).

Eddy and Underhill (1974) reported that, prior to the disappearance of the American Brook Lamprey from the Credit River (Scott County, Minnesota) some time after the late 1940s, spawning occurred during the period 5-20 May. Finally, PAC was provided with American Brook Lampreys collected from spawning groups observed in the North Branch Whitewater River on 21 and 22 April 1988.

\section{Discussion}

Several factors must be considered when assessing the timing of phenological events. These include the effect of latitude and the contribution of year-to-year 


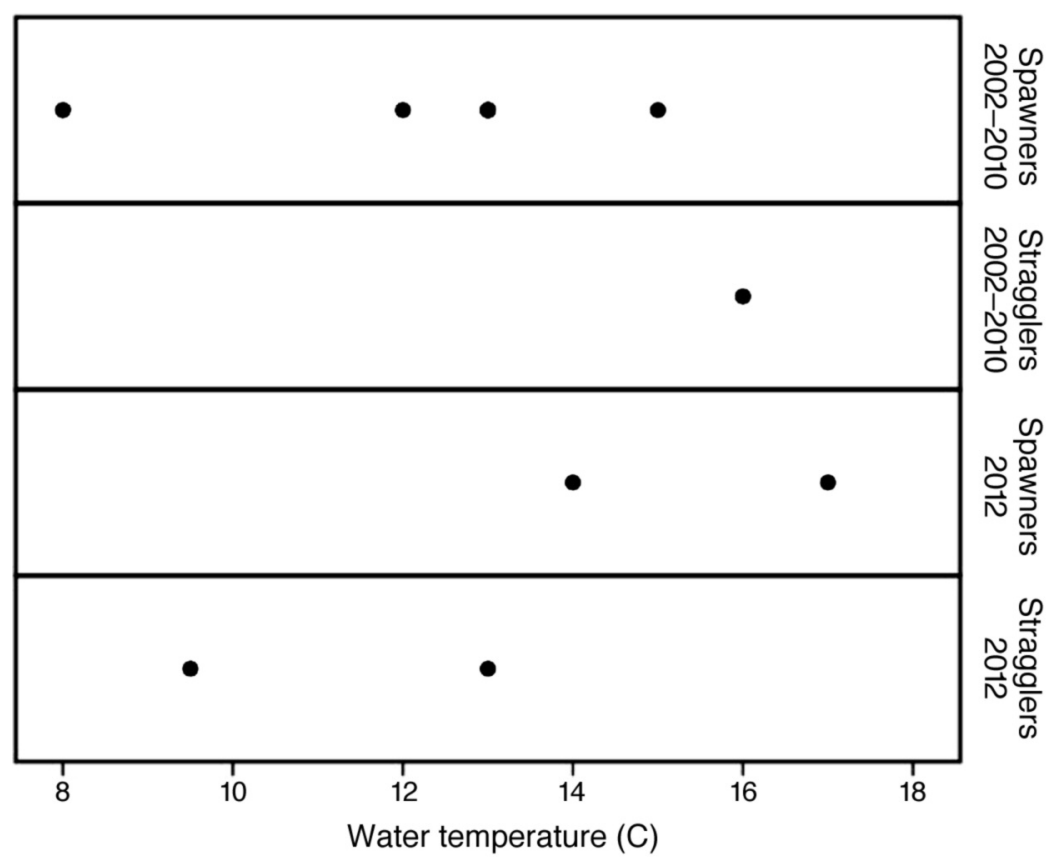

FIGURE 2. Dot plots of water temperature at which spawning-phase American Brook Lampreys (Lethenteron appendix) were observed in southeastern Minnesota during the period 2002-2010 and during the exceptionally warm spring of 2012. Data are presented separately for spawning groups and stragglers.

variability in climate. Finally, consideration of phenological phenomena in modern times must be placed in the context of climate change (e.g., Bradley et al. 1999).

Reproduction by fish species that spawn in the spring tends to occur later at higher latitudes. For example, the Slimy Sculpin (Cottus cognatus) spawns three to four weeks earlier in streams in Winona County (Majeski and Cochran 2009) than it does in a stream approximately $100 \mathrm{~km}$ to the north in Washington County (Petrosky and Waters 1975). Similarly, the American Brook Lamprey in Winona County spawns most often in late April (Mundahl and Sagan 2005; this study) but has been reported to spawn in early to mid-May approximately $85 \mathrm{~km}$ to the north in Scott County (Eddy and Underhill 1974).

The American Brook Lamprey has been reported to spawn in early March at the southern edge of its geographic distribution and as late as mid-June in the north (Table 2). However, our observations indicate that the range in spawning time among years within southeastern Minnesota encompasses over half the geographic range in spawning time.

Our limited data provide no evidence that climate change has resulted in the American Brook Lamprey spawning earlier in the spring in our region. Some early historical observations of spawning relatively late in the spring (May) are either confounded with the effect of latitude (Eddy and Underhill 1974) or are explicitly associated with a year with a "late spring" (Anonymous 1950*). Nevertheless, our observations that the American Brook Lamprey can spawn as much as a month early in a warm year suggest that this species has the capacity to respond to a climate shift.

Bradley et al. (1999) distinguished between species for which phenology is regulated by photoperiod and those that are regulated by temperature. Our data suggest that the timing of spawning by the American Brook Lamprey is responsive to water temperature. This is consistent with data for other lamprey species. For example, Cochran and Marks (1995) reported that the Silver Lamprey (Ichthyomyzon unicuspis) was captured during its upstream spawning migration earlier in warmer years. For both species, variability among years was greater with respect to day of year than with respect to temperature.

The American Brook Lamprey in southeastern Minnesota is found in streams that range from spring-fed, cold water streams (e.g., Beaver Creek in Winona County) to warm water streams fed to a greater extent by surface runoff (e.g., the Upper Iowa River). To the extent that streams fed primarily by groundwater are more resistant to the thermal effects of periods of extreme air temperature, there may be variability among streams in corresponding shifts in spawning time within years. In addition, Trautman (1981) suggested that 
TABLE 2. Previously reported spawning periods for the American Brook Lamprey (Lethenteron appendix) at various locations throughout its range from south to north. In some cases, spawning periods were inferred from the timing of collections of adults.

\begin{tabular}{llll}
\hline Location & Spawning period & Source & Notes \\
\hline Arkansas & 2 March & Tumlison and Tumlison (1999) & \\
Tennessee & March & Seagle and Nagel (1982) & Inferred from collections \\
Tennessee & 5 April & Etnier and Starnes (1993) & \\
Virginia & By mid-April & Jenkins and Burkhead (1994) & Latest adult seen on 16 April \\
Delaware & 28 March-4 April & Rohde et al. (1976) & \\
Ohio & 28 April & Trautman (1981) & \\
Michigan & 18-20 April & Young and Cole (1900) & \\
Michigan & After 10 April & Okkelberg (1921) & Peaked in early May \\
Michigan & 20 April-16 June & Morman (1979) & \\
New York & 8-20 May & Gage (1893, 1928) & \\
New York & 16 April & Dean and Sumner (1897) & \\
Massachusetts & 22 April-1 May & Hoff (1988) & \\
New Hampshire & 8 May & Sawyer (1960) & After spawning movements \\
Ontario & Late April-mid-May? & Kott (1971) & in mid-April-early May \\
Quebec & 11 May-4 June & Vladykov (1949) & Captured adults freely released gametes \\
Quebec & 3-20 May & Comtois et al. (2004) & \\
\hline \hline
\end{tabular}

spawning occurred later in larger streams that took longer to warm in the spring. Variability in spawning times may contribute to variability among streams in length of growing season, and it may help explain why the American Brook Lamprey in some southeastern Minnesota streams achieves much greater total lengths (Mundahl and Sagan 2005).

\section{Acknowledgements}

On 22 April 1988, when PAC was visiting Saint Mary's University of Minnesota to attend its Undergraduate Research Symposium, spawning American Brook Lampreys from the North Branch Whitewater River were obtained for him by Saint Mary's students Lenn Strapp and Scott Walker, the father of TSW. We are thankful for this data point, and we are grateful to more recent students who assisted us in the field, including Cassandra Hulett, Melissa Markert, Michael Mockler, Stephen Schmitt, and Jacob Zanon. Finally, we thank Saint Mary's University of Minnesota for its support of undergraduate research.

Documents Cited (marked * in text)

Anonymous. 1950. Not Sea Lamprey. Winona RepublicanHerald (May 18): 18.

Anonymous. 1956. Brook lamprey. Winona RepublicanHerald (May 9): 4.

Mentzer, M. 2012. Sturgeon, magnolia linked to same force. Green Bay Press-Gazette (May 25): C6.

Minnesota Climatology Working Group. 2012. Mild March 2012. Minnesota Climatology Working Group Climate Journal. http://climate.umn.edu/doc/journal/mild _march_2012.htm. (Accessed 16 July 2012).

U.S. National Oceanic and Atmospheric Administration. 2012. State of the climate: national overview for March 2012. U.S. National Oceanic and Atmospheric Administration (NOAA), National Climate Data Center. http://www .ncdc.noaa.gov/sotc/national/2012/3. (Accessed 16 July 2012).
U.S. National Weather Service. 2012. The record warmth of March 2012. U.S. National Weather Service Weather Forecast Office, Lacrosse, Wisconsin. http://www.crh.noaa .gov/arx/?n=2012Marchwarmth. (Accessed 16 July 2012).

Zimmer, R. 2012. Record warmth brings out wildlife. Green Bay Press-Gazette (May 25): C5.

\section{Literature Cited}

Bradley, N. L., A. C. Leopold, J. Ross, and W. Huffaker. 1999. Phenological changes reflect climate change in Wisconsin. Proceedings of the National Academy of Sciences of the United States of America 96: 9701-9704.

Cochran, P. A. 1984. Brook lampreys (Ichthyomyzon fossor and Lampetra appendix) in the Wisconsin portion of the Illinois River drainage. Transactions of the Wisconsin Academy of Sciences, Arts and Letters 72: 183-184.

Cochran, P. A. 2008. Observations on giant American Brook Lampreys (Lampetra appendix). Journal of Freshwater Ecology 23: 161-164.

Cochran, P. A., D. D. Bloom, and R. J. Wagner. 2008. Alternative reproductive behaviors in lampreys and their significance. Journal of Freshwater Ecology 23: 437-444.

Cochran, P. A., and J. E. Marks. 1995. Biology of the Silver Lamprey, Ichthyomyzon unicuspis, in Green Bay and the lower Fox River, with a comparison to the Sea Lamprey, Petromyzon marinus. Copeia 1995: 409-421.

Cochran, P. A., M. E. Sneen, and A. P. Gripentrog. 1993. Notes on the biology of the American Brook Lamprey (Lampetra appendix) in Wisconsin. Transactions of the Wisconsin Academy of Sciences, Arts and Letters 81: 39-46.

Comtois, A., F. Chapleau, C. B. Renaud, H. Fournier, B. Campbell, and R. Pariseau. 2004. Inventaire printanier d'une frayère multispécifique: l'ichthyofaune des rapides de la rivière Gatineau, Québec. Canadian Field-Naturalist 118: 521-529.

Dean, B., and F. B. Sumner. 1897. Notes on the spawning habits of the brook lamprey (Petromyzon wilderi). Transactions of the New York Academy of Science 16: 321-324.

Eddy, S., and J. C. Underhill. 1974. Northern Fishes. Third edition. University of Minnesota Press, Minneapolis, Minnesota. 414 pages. 
Etnier, D. A., and W. B. Starnes. 1993. The Fishes of Tennessee. University of Tennessee Press, Knoxville, Tennessee. 681 pages.

Fago, D. 1983. Distribution and relative abundance of fishes in Wisconsin. II. Black, Trempealeau, and Buffalo river basins. Wisconsin Department of Natural Resources Technical Bulletin No. 140. 120 pages.

Gage, S. H. 1893. The lake and brook lampreys of New York, especially those of Cayuga and Seneca lakes. Pages 421493 in The Wilder Quarter-Century Book: A Collection of Original Papers Dedicated to Professor Burt Green Wilder at the Close of His Twenty-fifth Year of Service in Cornell University, 1868-1893. Comstock, Ithaca, New York.

Gage, S. H. 1928. The lampreys of New York State-life history and economics. Pages 158-191 in A Biological Survey of the Oswego River System. Supplemental to the 17th Annual Report, 1927, New York Conservation Department. J. B. Lyon Company, Printers, Albany, New York.

Jenkins, R. E., and N. M. Burkhead. 1994. Freshwater Fishes of Virginia. American Fisheries Society, Bethesda, Maryland. 1079 pages.

Hoff, J. G. 1988. Some aspects of the ecology of the American Brook Lamprey, Lampetra appendix, in the Mashpee River, Cape Cod, Massachusetts. Canadian Field-Naturalist 102: 735-v737.

Kott, E. 1971. Characteristics of pre-spawning American Brook Lampreys from Big Creek, Ontario. Canadian FieldNaturalist 85: 235-240.

Lang, N. A., K. Roe, C. Renaud, H. Gill, I. Potter, J. Freyhof, A. Naseka, P. Cochran, H. Espinosa-Pérez, E. Habit, B. Kuhajda, D. Neely, Y. Reshetnikov, V. Salnikov, M. Stoumboudi, and R. Mayden. 2009. Novel relationships among lampreys (Petromyzontiformes) revealed by a taxonomically comprehensive molecular dataset. Pages 41-55 in L. R. Brown, S. D. Chase, M. G. Mesa, R. J. Beamish, and P. B. Moyle (editors). Biology, Management and Conservation of Lampreys in North America. American Fisheries Society, Symposium 72, Bethesda, Maryland.

Majeski, M. J., and P. A. Cochran. 2009. Spawning season and habitat use of Slimy Sculpin (Cottus cognatus) in southeastern Minnesota. Journal of Freshwater Ecology 24: 301-307.

Morman, R. H. 1979. Distribution and ecology of lampreys in the Lower Peninsula of Michigan, 1957-75. Great Lakes Fishery Commission Technical Report No. 33. 59 pages.
Mundahl, N. D., C. Erickson, M. R. Johnston, G. A. Sayeed, and S. Taubel. 2005. Diet, feeding rate, and assimilation efficiency of American Brook Lamprey. Environmental Biology of Fishes 72: 67-72.

Mundahl, N. D., and R. A. Sagan. 2005. Spawning ecology of the American Brook Lamprey, Lampetra appendix. Environmental Biology of Fishes 73: 283-292.

Mundahl, N. D., G. A. Sayeed, S. Taubel, C. Erickson, A. Zalatel, and J. Cousins. 2006. Densities and habitat of American Brook Lamprey (Lampetra appendix) larvae in Minnesota. American Midland Naturalist 156: 11-22.

Okkelberg, P. 1921. The early history of the germ cell in the brook lamprey, Entosphenus wilderi (Gage), up to and including the period of sex differentiation. Journal of Morphology 35: 1-151.

Petrosky, C. E., and T. F. Waters. 1975. Annual production by the Slimy Sculpin population in a small Minnesota trout stream. Transactions of the American Fisheries Society 104: 237-244.

Rohde, F. C., R. G. Arndt, and J. C. S. Wang. 1976. Life history of the freshwater lampreys, Okkelbergia aepyptera and Lampetra lamottenii (Pisces: Petromyzonidae) on the Delmarva Peninsula (East Coast, United States). Bulletin of the Southern California Academy of Science 75: 99111.

Sawyer, P. J. 1960. A new geographic record for the American Brook Lamprey, Lampetra lamottei. Copeia 1960: 136137.

Seagle, H. H., and J. W. Nagel. 1982. Life cycle and fecundity of the American Brook Lamprey, Lampetra appendix, in Tennessee. Copeia 1982: 362-366.

Trautman, M. B. 1981. The Fishes of Ohio. Second edition. Ohio State University Press, Columbus, Ohio. 782 pages.

Tumlison, R., and C. Tumlison. 1999. An extralimital population of Lampetra appendix (Petromyzontidae) in southwestern Arkansas. Southwestern Naturalist 44: 106-108.

Vladykov, V. D. 1949. Quebec lampreys (Petromyzonidae) I. List of species and their economical importance. Department of Fisheries, Province of Quebec, Contribution No. 26. 67 pages.

Young, H. T., and L. J. Cole. 1900. On the nesting habits of the brook lamprey (Lampetra wilderi). American Naturalist 34: 617-620.

Received 26 July 2012

Accepted 12 October 2012 